\title{
ANALISIS TINDAK TUTUR DALAM WACANA IKLAN RADIO
}

\author{
Winda Ayu Cahya Fitriani \\ IKIP PGRI MADIUN \\ winda.ayu.cahya@gmail.com
}

\begin{abstract}
ABSTRAK
Penelitian ini bertujuan untuk menganalisis tindak tutur dalam iklan radio wacana lisan. Teori dalam penelitian ini adalah teori tindak tutur (Austin dan Searle), yang meliputi distribusi lokusi, ilokusi, dan perlokusi. Di iklan radio ada beberapa ucapan yang berisi lokusi, ilokusi, dan perlokusi. Metode yang digunakan dalam penelitian ini adalah deskriptif kualitatif. Penelitian ini mengambil data dari wacana iklan radio "Extra Joss dan Mie Sedap". Sumber data dalam penelitian ini adalah transkripsi rekaman data di RRI Pro 2 Fm Surakarta pada 2 Januari 2014. Validitas data menggunakan teori triangulasi. Analisis data menggunakan metode rujukan. Hasil penelitian menunjukkan bahwa tindak tutur yang muncul dalam iklan "Extra Joss" yaitu tindak tutur lokusi, ilokusi, perlokusi. Sedangkan tindak tutur yang muncul dalam iklan "Mie Sedap" yaitu pelokalan, ilokusi, dan perlokusi.
\end{abstract}

Kata Kunci: Tindak tutur, wacana iklan

\section{A. PENDAHULUAN}

Dunia periklanan saat ini sudah berkembang pesat seiring dengan berkembangnya dunia teknologi dan kemajuan dalam bidang ekonomi. Perkembangan dunia periklanan banyak didukung oleh media dan teknologi, baik media visual, seperti koran, majalah, maupun media audiovisual, seperti televisi dan radio. Iklan merupakan salah satu bentuk informasi yang secara tidak langsung bisa memengaruhi gaya hidup manusia melalui bahasanya. Bahasa yang digunakan dalam dunia periklanan merupakan bahasa informatif yang mempunyai tujuan persuasif.

Salah satu bentuk iklan audiovisual yang sudah ada sejak dahulu dan tidak dimakan zaman adalah iklan radio. Iklan radio merupakan suatu wujud komunikasi lisan yang disampaikan seseorang kepada khalayak ramai dengan tujuan untuk menarik perhatian masyarakat terhadap barang atau jasa yang mereka tawarkan. Iklan radio merupakan sebuah bentuk komunikasi lisan yang mempunyai efek magis pada pendengarnya. Efek magis yang ditimbulkan dari iklan radio berasal dari penggunaan bahasa yang ditimbulkan. Penggunaan bahasa dalam iklan yang dimaksud adalah intonasi bicara, ekspresi suara, serta ide cerita yang muncul melalui suaranya. Suara-suara yang ada didalam sebuah iklan radio merupakan 
Lingua Rima: Jurnal Pendidikan Program Studi Bahasa dan Sastra Indonesia

Vol. 8 No. 1 Januari 2019

sebuah tindak tutur. Dimana petutur menyampaikan maksud dan tujuannya kepada lawan tutur melalui bahasanya.

Di dalam iklan radio terdapat hal yang bisa dianalisis menggunakan analisis wacana, yaitu melalui tindak bahasa atau tindak tuturnya. Analisis wacana adalah aspek yang harus diperhatikan oleh para ilmuwan bahasa, karena di dalam sebuah tuturan lisan terdapat makna wacana yang terkandung didalamnya. Austin (dalam Leech, 1993: 113) menyatakan bahwa ada tiga jenis tindakan yang dilakukan seseorang pada saat dia menghasilkan ujaran yaitu tindak lokusi (locutionary act), tindak ilokusi (illocutionary act) dan tindak perlokusi (perlocutionary act).

Wacana menurut Eriyanto (2001: 3) adalah unit bahasa yang lebih besar dari kalimat. Analisis wacana dalam studi linguistik ini merupakan reaksi dari bentuk linguistik formal yang lebih memperhatikan pada unit kata, frase, atau kalimat semata tanpa melihat keterkaitan di antara unsur tersebut. Lebih lanjut, Eriyanto (2001: 5) menyatakan bahwa analisis wacana dimaksudkan sebagai suatu analisis untuk membongkar maksud-maksud dan makna-makna tertentu. Wacana adalah suatu upaya pengungkapan maksud tersembunyi dari subjek yang mengemukakan suatu pernyataan.

\section{B. KAJIAN TEORI}

Para ahli bahasa telah menyepakati bahwa wacana merupakan satuan bahasa yang paling besar yang digunakan dalam komunikasi. Satuan-satuan bahasa yang ada di bawahnya secara berurutan adalah kalimat, frase, kata dan bunyi. Wacana terbentuk karena rangkaian bunyi membentuk kata, rangkaian kata membentuk frase, rangkaian frase membentuk kalimat dan yang selanjutnya rangkaian kalimat membentuk wacana.

Wacana dapat terjadi apabila dalam situasi tutur terdapat penutur atau penyapa (addressor) dan petutur (addresse). Dalam wacana lisan, penutur adalah pembicara sedangkan petutur adalah pendengar atau penyimak. Dalam wacana tulis, penutur adalah penulis sedangkan petutur adalah pembaca. Dalam sebuah wacana, harus ada unsur penyapa dan pesapa. Menurut Rani et al (2006: 4) tanpa adanya kedua unsur itu, tidak akan terbentuk suatu wacana.

Tindak tutur adalah aktivitas bertutur yang dihasilkan sebagai bagian dari interaksi sosial (Sumarsono, 2004: 323). Dalam beberapa hal kita memakai tutur untuk membentuk tindakan, bahkan untuk bertindak. Teori tindak tutur meneliti tentang makna kalimat, tidak menganalisis struktur kalimat. Rani et al (2006: 159) menyatakan bahwa tindak tutur dalam ujaran suatu kalimat merupakan penentu makna kalimat itu. Namun, makna suatu kalimat 
Lingua Rima: Jurnal Pendidikan Program Studi Bahasa dan Sastra Indonesia

Vol. 8 No. 1 Januari 2019

tidak ditentukan oleh satu-satunya tindak tutur seperti yang berlaku dalam kalimat yang sedang diujarkan itu, tetapi selalu dalam prinsip adanya kemungkinan untuk menyatakan secara tepat apa yang dimaksudkan oleh penuturnya. Hal ini memungkinkan dalam setiap tindak tutur, penutur menuturkan kalimat yang unik karena dia berusaha menyesuaikan ujaran dengan konteksnya.

Menurut Austin dan Searle (dalam Setiawan, 2010: 12) menyatakan semua ujaran itu mengungkapkan suatu tindak. Semua ujaran itu dapat dikategorikan dalam dua kategori yang luas, yakni "melakukan sesuatu atau tindak pelaku (performatives)" dan "yang menyatakan sesuatu atau tindak penyata bahasa (constatives)".

Austin dan Searle (dalam Setiawan, 2010: 12-13) membagi tindak bahasa menjadi 3, yaitu:

a. Lokusi (Locutionary act), yang mengatakan sesuatu, mirip dengan prediksi atau proposisi (predication). Tindak lokusi adalah tindak tutur untuk menyatakan sesuatu. Tindak tutur ini disebut sebagai "The act of saying something". Austin (dalam Wibisono, 1991:17) mengemukakan bahwa tindak lokusi sebagai salah satu jenis tindak bahasa yang tidak disertai tanggung jawab bagi penuturnya untuk melakukan isi tuturannya, lebih umum sifatnya jika dibandingkan dengan jenis tindak bahasa yang lain.

b. Ilokusi (Illocutionary act), yang melakukan suatu tindak, seperti : mengungakpkan suatu perasaan, sikap, kepercayaan atau tujuan sesuai dengan suatu konteks tertentu. Tindak ilokusi adalah tindak tutur untuk melakukan sesuatu. Tindak ilokusi ini disebut sebagai "The act of doing something”. Dalam hubungannya dengan tindak bahasa ilokusi ini, Austin mengatakan bahwa tindak ilokusi adalah aktivitas bertutur kalimat yang disertai tanggung jawab bagi si penuturnya untuk melakukan suatu tindakan tertentu. Ditinjau dari bentuk tuturannya, daya ilokusi dibedakan menjadi daya ilokusi langsung dan daya ilokusi tidak langsung. Daya ilokusi langsung adalah daya ilokusi yang muncul dalam pesan yang disampaikan penutur kepada lawan tutur secara langsung tanpa dialog. Daya ilokusi tidak langsung adalah daya ilokusi yang muncul dalam dialog, penutur menyampaikan pesannya secara tidak langsung kapada petutur tetapi melalui dialog yang digunakan.

c. Perlokusi (Perlocutionary act), yakni yang merupakan efek atau akibat (dari tindak ilokusi si pembicara) pada lawan bicara. Tindak perlokusi adalah tindak tutur untuk mempengaruhi atau untuk mendapatkan efek bagi yang 
Lingua Rima: Jurnal Pendidikan Program Studi Bahasa dan Sastra Indonesia

Vol. 8 No. 1 Januari 2019

mendengarkan. Efek atau pengaruh itu dapat secara sengaja atau tidak sengaja dikreasikan oleh penuturnya. Tindak tutur ini disebut "The act of affecting someone".

\section{METODE PENELITIAN}

Jenis penelitian dalam penelitian ini adalah penelitian kualitatif dengan metode deskriptif. Data yang terdapat dalam penelitian ini adalah data-data berupa tindak tutur yang terdapat dalam wacana pada iklan radio "Laki Minum Extra Joss dan Mie Sedap". Data tersebut merupakan transkripsi data hasil rekaman pada iklan radio RRI Pro 2 Fm Surakarta pada tanggal 2 Januari 2014. Sumber data dalam penelitian ini adalah wacana iklan radio yang terdapat di Surakarta. Adapun data yang diambil dari rekaman iklan radio diperoleh melalui stasiun radio RRI Pro 2 Fm. Peneliti merekam tuturan dalam iklan radio tersebut lalu mentranskripkan tuturan tersebut dalam bentuk data tertulis.

Teknik sampling yang digunakan dalam penelitian ini adalah purposive sampling atau teknik pengambilan data berdasarkan tujuan tertentu. Purposive sampling yaitu sumber data yang digunakan disini tidak sebagai sumber data yang mewakili populasinya tetapi lebih mewakili informasinya. Guna menjamin validitas data yang diperoleh dalam penelitian ini, maka validitas data yang digunakan adalah teknik triangulasi. Penelitian ini menggunakan triangulasi teori. Analisis data yang digunakan dalam penelitian ini yaitu metode simak. Metode simak adalah metode yang dilakukan dengan menyimak, yaitu menyimak penggunaan bahasa. Teknik dasar dari metode ini yaitu teknik sadap, maksudnya peneliti dalam memanfaatkan data dengan segala kecerdikan dan kemauan harus menyadap pembicaraan seseorang. Dalam hal ini, peneliti menyadap tindak tutur dalam wacana iklan radio "Laki Minum Extra Joss dan Mie Sedap” yang ada di radio RRI Pro 2 Fm Surakarta.

\section{PEMBAHASAN}

\section{Transkrip Percakapan Iklan Radio "Extra Joss"}

Orang 1 : Jadi awak biasa berangkat kerja waktu orang masih ngorok....... ngrok...ngrok...ngrok.........fiuh.....(suara orang ngorok)

Ah...mana kebun jauh pula, 2 jam perjalanan......ngeng....... ngeng....ngeng..........(suara motor)

Nah sampe di kebun, alamak bahaya sudah menunggu, macam tertimpa bonggol kelapa sawit, gedibug.....macam terkena getah, atau racun, racun serangga bahkan bertemu harimau aum.....aum (suara auman harimau), seram kan.

Hah itulah resiko awak tiap hari, biar ada minyak goreng buat 
Lingua Rima: Jurnal Pendidikan Program Studi Bahasa dan Sastra Indonesia

Vol. 8 No. 1 Januari 2019

inang-inang masak. Makanya tidak semua orang bisa jadi buruh tani kelapa sawit. Ngerti kalian.

Orang 2 : Buruh tani kepala sawit itu, laki, laki dan nyari rasa-rasa. Laki minum Extra Joss. Gingseng Korea dan royal jelly, ledakkan tenaga laki.

Tindak tutur yang terdapat dalam iklan radio "Extra Joss" ini terjadi antara 2 orang, orang 1 merupakan illustrator iklan, sedangkan orang 2 merupakan narrator iklan. Terdapat tindak lokusi dalam penelitian ini, yaitu kedua tokoh yang ada dalam iklan tersebut. Tindak tutur ini ditemukan dalam kalimat :

Kalimat yang diucapkan orang 1 : Jadi awak biasa berangkat kerja waktu orang masih ngorok. Ah...mana kebun jauh pula, 2 jam perjalanan. Hah itulah resiko awak tiap hari, biar ada minyak goreng buat inang-inang masak. Makanya tidak semua orang bisa jadi buruh tani kelapa sawit.

Kalimat yang diucapkan orang 2 : Buruh tani kepala sawit itu, laki, laki dan nyari rasa-rasa. Laki minum Extra Joss. Gingseng Korea dan royal jelly, ledakkan tenaga laki.

Dalam tindak lokusi seorang penutur mengatakan sesuatu secara pasti, gaya bahasa si penutur langsung dihubungkan dengan sesuatu yang diutamakan dalam isi tuturan. Dengan demikian, sesuatu yang diutamakan dalam tindak bahasa lokusi adalah isi tuturan yang diungkapkan oleh penutur. Isi tuturan dalam iklan tersebut sebagai berikut:

Buruh tani kepala sawit itu, laki, laki dan nyari rasa-rasa. Laki minum Extra Joss. Gingseng Korea dan royal jelly, ledakkan tenaga laki.

Melalui ucapan buruh tani kepala sawit itu, laki, laki dan nyari rasa-rasa dapat menentukan bahwa tindakan yang dilakukan oleh kalimat tersebut mengarah pada semua orang. Dalam kalimat tersebut ada keharusan agar pendengar mengikuti apa yang diucapkan oleh penutur. Bahwa seorang laki-laki itu adalah orang yang kuat, dan untuk membentuk kekuatan itu, seorang laki-laki harus minum Extra Joss. Tindak lokusi ini lebih menekankan gaya bicara penutur dalam mengungkapkan sesuatu dan mengharuskan penutur untuk melaksanakan isi tuturannya. Terdapat sesuatu yang diutamakan dalam isi tuturan, laki minum Extra Joss, berarti bahwa si penutur benar-benar telah, sedang, atau akan melaksanakan isi tuturan.

Tindak tutur kedua yang muncul dalam iklan tersebut adalah ilokusi. Daya ilokusi yang dihasilkan oleh iklan radio "Extra Joss" merupakan daya ilokusi tidak langsung. Daya ilokusi tidak langsung dapat ditandai dengan sebuah dialog. Penutur menyampaikan pesannya secara 
Lingua Rima: Jurnal Pendidikan Program Studi Bahasa dan Sastra Indonesia

Vol. 8 No. 1 Januari 2019

tidak langsung kepada petutur tetapi melalui dialog yang digunakan. Ditinjau dari jenisnya, daya ilokusi yang dimiliki oleh iklan tersebut adalah jenis mengajak. Ajakan dari kedua tokoh dalam iklan mengharapkan agar pendengar melakukan apa yang dikatakan oleh petutur. Dalam tindak tutur ilokusi didapatkan sesuatu daya atau kekuatan (force) yang mewajibkan bagi si penuturnya untuk melakukan sesuatu tindakan tertentu.

Dapat dilihat pada penggalam kalimat di bawah ini:

(Kalimat yang diucapkan orang 1) : Nah sampe di kebun, alamak bahaya sudah menunggu, macam tertimpa bonggol kelapa sawit, gedibug.....macam terkena getah, atau racun, racun serangga bahkan bertemu harimau aum.....aum (suara auman harimau), seram kan. Hah itulah resiko awak tiap hari, biar ada minyak goreng buat inang-inang masak. Makanya tidak semua orang bisa jadi buruh tani kelapa sawit. Ngerti kalian.

(Kalimat yang diucapkan orang 2) : Buruh tani kepala sawit itu, laki, laki dan nyari rasarasa. Laki minum Extra Joss. Ledakkan tenaga laki

Dengan memperhatikan kalimat yang muncul pada penggalan iklan diatas, membuat pendengar (lawan tutur) seakan teradopsi untuk mempercayai apa yang dikatakan oleh penutur. Seseorang harus membeli produk tersebut agar bisa seperti seorang lelaki yang kuat dan seperti koboi yang menang dalam perang. Jenis tindak tutur yang muncul dalam iklan tersebut, seperti teori Searle adalah tindak tutur komisif. Dimana tindak tutur komisif itu adalah tindak tutur yang mendorong penutur melakukan sesuatu, seperti mengusulkan sebuah barang. Verba komisif yang muncul mengacu kepada suatu penawaran akan produk yang mereka punya, dan tiada duanya. Tindak tutur komisif dapat dilihat pada penggalan kalimat berikut: "Laki minum Extra Joss. Ledakkan tenaga laki”.

Kemudian jenis tindak tutur yang muncul adalah tindak tutur direktif. Artinya tindak tutur yang berfungsi mendorong pendengar melakukan sesuatu, seperti menyuruh, meminta, menasehati. Verba direktif yang ada mengacu pada memberi perintah dan menganjurkan untuk mengonsumsi produk yang mereka punya. Tindak tutur direktif pada iklan tersebut dapat dilihat pada potongan kalimat berikut : "Buruh tani kepala sawit itu, laki, laki dan nyari rasa-rasa. Laki minum Extra Joss. Ledakkan tenaga laki”.

Tindak tutur ketiga yakni perlokusi. Tindak tutur perlokusi merupakan tindakan melakukan sesuatu sebagai efek lokusi dan ilokusi. Tindak tutur perlokusi mencerminkan reaksi atau efek ujaran penutur kepada mitra tutur.

Tindak ilokusi yang muncul pada tuturan iklan diatas adalah sebagai berikut:

"Buruh tani kepala sawit itu, laki, laki dan nyari rasa-rasa. Laki minum Extra Joss. Gingseng Korea dan royal jelly, ledakkan tenaga laki”. 


\section{Transkrip Percakapan Iklan Radio "Mie Sedap"}

Narator : Ini reaksi kalau kita ketahuan bohong

Wanita : Ih, Loe bohongin gue?

Pria : Udah udah udah, enough. Gue nggak percaya loe lagi.

Wanita : Nggak usah janji.

Wanita : Bohong lagi bohong lagi

Pria : Eh, emang tukang bohong.

Wanita : Sering-sering aja loe bohongin gue.

Pria : Sebel Gue.

Wanita : Bete

Pria : Sebel, resek.

Wanita : Ih, benci.

Pria : Kibul, kibul.

Wanita : Huh, kesel kesel kesel.

Narator : Soal kata lidah bisa bohong. Udah, soal rasa lidah nggak bisa bohong. Pas lidahmu nikmatin enaknya mie sedap.

Wanita : Ehm, sedap.

Wanita : Enak banget.

Wanita : Ehm, gila banget, enak.

Narator : Tuh kan lidah ga bisa bohong. Rasa mie sedap, jelas terasa sedapnya.

Tindak tutur yang terdapat dalam iklan radio "Mie Sedap" ini terjadi antara 3 orang, orang 2 merupakan illustrator iklan, sedangkan orang 1 merupakan narrator iklan. Terdapat tindak lokusi dalam penelitian ini, yaitu kedua tokoh yang ada dalam iklan tersebut. Tindak tutur ini ditemukan dalam kalimat :

Narator : Soal kata lidah bisa bohong. Udah, soal rasa lidah nggak bisa bohong. Pas lidahmu nikmatin enaknya mie sedap.

Wanita : Ehm, sedap.

Wanita : Enak banget.

Wanita : Ehm, gila banget, enak.

Narator : Tuh kan lidah ga bisa bohong. Rasa mie sedap, jelas terasa sedapnya.

Melalui ucapan Soal kata lidah bisa bohong. Udah, soal rasa lidah nggak bisa bohong. Pas lidahmu nikmatin enaknya mie sedap dapat menentukan bahwa tindakan yang dilakukan 
Lingua Rima: Jurnal Pendidikan Program Studi Bahasa dan Sastra Indonesia

Vol. 8 No. 1 Januari 2019

oleh kalimat tersebut mengarah pada semua orang. Dalam kalimat tersebut ada keharusan agar pendengar mengikuti apa yang diucapkan oleh penutur.

Tindak tutur kedua yang muncul dalam iklan tersebut adalah ilokusi. Daya ilokusi yang dihasilkan oleh iklan radio "Mie Sedap" merupakan daya ilokusi tidak langsung. Daya ilokusi tidak langsung dapat ditandai dengan sebuah dialog. Penutur menyampaikan pesannya secara tidak langsung kepada petutur tetapi melalui dialog yang digunakan. Ditinjau dari jenisnya, daya ilokusi yang dimiliki oleh iklan tersebut adalah jenis mengajak. Ajakan dari kedua tokoh dalam iklan mengharapkan agar pendengar melakukan apa yang dikatakan oleh petutur. Dalam tindak tutur ilokusi didapatkan sesuatu daya atau kekuatan (force) yang mewajibkan bagi si penuturnya untuk melakukan sesuatu tindakan tertentu.

Dapat dilihat pada penggalam kalimat di bawah ini:

Narator : Soal kata lidah bisa bohong. Udah, soal rasa lidah nggak bisa bohong. Pas lidahmu nikmatin enaknya mie sedap.

Narator : Tuh kan lidah ga bisa bohong. Rasa mie sedap, jelas terasa sedapnya.

Dengan memperhatikan kalimat yang muncul pada penggalan iklan diatas, membuat seseorang harus membeli produk tersebut, karena hanya produk tersebut yang tidak pernah bohong dalam hal rasa, tidak seperti produk yang lain. Jenis tindak tutur yang muncul dalam iklan tersebut adalah tindak tutur komisif dan tindak tutur direktif. Tindak tutur direktif pada iklan tersebut dapat dilihat pada potongan kalimat berikut : Tuh kan lidah ga bisa bohong. Rasa mie sedap, jelas terasa sedapnya.

Tindak tutur ketiga yakni perlokusi. Tindak tutur perlokusi merupakan tindakan melakukan sesuatu sebagai efek lokusi dan ilokusi. Tindak tutur perlokusi mencerminkan reaksi atau efek ujaran penutur kepada mitra tutur. Tindak perlokusi yang muncul pada tuturan iklan diatas adalah sebagai berikut:

"Soal kata lidah bisa bohong. Udah, soal rasa lidah nggak bisa bohong. Pas lidahmu nikmatin enaknya mie sedap.Tuh kan lidah ga bisa bohong. Rasa mie sedap, jelas terasa sedapnya".

\section{E. SIMPULAN DAN SARAN}

Bahasa digunakan manusia untuk menyampaikan ide, berita, perasaan, harapan dan sebagainya. Bahasa adalah suatu sistem lambang bunyi yang arbitrer, digunakan oleh suatu masyarakat untuk bekerjasama, berkomunikasi dan mengidentifikasi diri. Dengan adanya bahasa, manusia dapat melakukan komunikasi baik secara lisan maupun dengan cara tulis. 
Secara lisan, manusia dapat menggunakan bahasa untuk berbicara dengan orang lain dalam kehidupan sehari-hari, sedangkan secara tulis, manusia dapat menggunakan bahasa untuk menulis surat, buku, majalah atau catatan-catatan lain agar dibaca oleh orang lain.

Iklan merupakan suatu alat informasi atas suatu produk yang menggunakan bahasa persuasif. Iklan bisa dianalisis melalui analisis wacana. Selain tindak tutur, masih banyak sekali analisis wacana yang terdapat dalam iklan, namun jika kita mau menelaah lebih banyak. Maka dari itu untuk memperluas ilmu tentang analisis iklan, maka perlu kajian yang lebih mendalam lagi.

\section{F. DAFTAR PUSTAKA}

Eriyanto. 2001. Analisis Wacana. Yogyakarta: LKiS Yogyakarta.

Leech, Geoffrey. 1993. Prinsip-prinsip Pragmatik. Jakarta: Universitas Indonesia.

Rani, Abdul dkk. 2006. Analisis Wacana Sebuah Kajian Bahasa Dalam Pemakaian. Malang: Bayumedia.

Semi, Atar. 1993. Anatomi Sastra. Bandung: Angkasa.

Setiawan, Budi. 2010. Analisis Wacana dan Pembelajaran Bahasa. Salatiga: Widya Sari Press.

Sumarsono dan Paina Partana. 2004. Sosiolinguistik. Yogyakarta: Pustaka Pelajar.

Wibisono, Bambang. 1991. "Tindak Bahasa Guru dalam Mengajarkan Struktur: (Studi Kasus di SMA Negeri 2 Jember)”. Malang: Institut Keguruan dan Ilmu Pendidikan Malang. 